\title{
Effect of Heat Treatment on Microstructure and Stress Rupture Properties of a Ni-Mo-Cr-Fe Base Corrosion-Resistant Superalloy
}

\author{
Tao Liu ${ }^{1} \cdot$ Mei Yang ${ }^{1} \cdot$ Jun-Song Wang ${ }^{2} \cdot$ Jia-Sheng Dong $^{3} \cdot$ Li Wang $^{3} \cdot$ Lang-Hong Lou ${ }^{3}$
}

Received: 9 July 2018/Revised: 1 September 2018/Published online: 5 December 2018

(C) The Chinese Society for Metals and Springer-Verlag GmbH Germany, part of Springer Nature 2018

\begin{abstract}
The influences of heat treatment and test condition on the microstructure and stress rupture properties of a Ni-Mo-Cr-Fe base corrosion-resistant superalloy have been investigated in this paper. Optical microscope and scanning electron microscope were employed for the microstructure observation, and X-ray diffraction, electron probe micro-analyzer, and transmission electron microscope were used for phase determination. It was found that the grain size increased and the volume fractions of initial $\mathrm{M}_{6} \mathrm{C}$ carbides decreased along with the increase in solution treatment temperature. When tested at $650{ }^{\circ} \mathrm{C} / 320 \mathrm{MPa}$, the stress rupture lives decreased with the increase in solution treatment temperature, but the stress rupture lives increased slightly at first and then decreased for the samples solution heat treated at $1220{ }^{\circ} \mathrm{C}$ when tested at $700{ }^{\circ} \mathrm{C} / 240 \mathrm{MPa}$. The elongations showed the descendent trends under these two conditions. The stress rupture life and elongation for the aged samples all showed a noticeable improvement at $650{ }^{\circ} \mathrm{C} / 320 \mathrm{MPa}$, but there was no noticeable improvement at $700{ }^{\circ} \mathrm{C} / 240 \mathrm{MPa}$. The reasons can be attributed to the grain size, test conditions, and the initial and secondary carbides.
\end{abstract}

Keywords Corrosion-resistant superalloy $\cdot$ Heat treatment $\cdot$ Stress rupture properties $\cdot$ Secondary carbides

\section{Introduction}

As one of the most promising next generation reactors, molten salt breeder reactor (MSBR) has attracted more and more attentions in recent years $[1,2]$. The polycrystalline $\mathrm{Ni}-\mathrm{Mo}-\mathrm{Cr}-\mathrm{Fe}$ superalloy (Hastelloy $\mathrm{N}$ ), which was developed at Oak Ridge National Laboratory (ORNL) in $1960 \mathrm{~s}$, is the most important structural materials used in this system $[3,4]$. However, the investigation was terminated in 1970s, and there are still many problems [5]. Driven by the materials demand of MSBR, a novel Ni$\mathrm{Mo}-\mathrm{Cr}-\mathrm{Fe}$ alloy with excellent corrosion resistance and

Available online at http://link.springer.com/journal/40195

Jia-Sheng Dong

djs@imr.ac.cn

$\triangle$ Li Wang

wangli@imr.ac.cn

1 Jiangsu University of Technology, Changzhou 213001, China

2 Harbin Engineering University, Harbin 150001, China

3 Institute of Metal Research, Chinese Academy of Sciences, Shenyang 110016, China good high-temperature strength was developed [6]. It was reported by Shingledecker et al. [7] that the coarse grain is beneficial to the stress rupture properties of the alloy. But the results of Jayakumar et al. [8] showed that fine grain is beneficial to the stress rupture properties. It was also presented by Yao et al. [9] that it is not good for the stress rupture properties if the grain size is too large or too small. Heat treatment will change the microstructure and the stress rupture properties of the alloy [10-17]. Therefore, heat treatment optimization is considered as an important method to improve the properties of the alloy. In addition, the properties of the alloy were not only affected by the microstructure but also influenced by the service conditions $[18,19]$. However, no papers could be found in the open literature concerning the effect of heat treatment on the microstructure and stress rupture properties of the alloy. In addition, the service temperature and stress level are different for different components in MSBR [20]. Thus, it is necessary to investigate the influence of heat treatment on the microstructure and properties under different test conditions.

In this paper, different solution heat treatment temperatures were applied. The effect of heat treatment 
temperature on the microstructure and stress rupture properties of the alloy has been investigated, and the mechanisms were also discussed.

\section{Experimental Details}

$\mathrm{Ni}-\mathrm{Mo}-\mathrm{Cr}-\mathrm{Fe}$ base superalloy was prepared by a vacuum induction melting and followed by vacuum consumable remelting. The ingot $(508 \mathrm{~mm}$ in diameter) was homogenized at $1180{ }^{\circ} \mathrm{C}$ for $2.5 \mathrm{~h}$ and subsequently forged into bars of $\Phi 60 \mathrm{~mm}$. Then, it was hot-rolled into round bars of $16 \mathrm{~mm}$ in diameter. The chemical composition (in wt\%) of the alloy is given in Table 1 .

The bars were subjected to the solution heat treatment at $1140{ }^{\circ} \mathrm{C}, 1180{ }^{\circ} \mathrm{C}$, and $1220^{\circ} \mathrm{C}$, respectively, for $1 \mathrm{~h}$ followed by water quenching. In order to find out the effect of aging, some bars solution heat treated at $1180{ }^{\circ} \mathrm{C}$ were aged at $900{ }^{\circ} \mathrm{C}$ for $2 \mathrm{~h}$ followed by water quenching. The samples for microstructure observation were cut vertical to the as-forged direction from the as-forged and heat-treated bars. All the bars were machined into cylindrical creep samples with gauge size of $5 \mathrm{~mm}$ in diameter and $30 \mathrm{~mm}$ in length. Stress rupture tests were conducted at $650{ }^{\circ} \mathrm{C} /$ $320 \mathrm{MPa}$ and $700{ }^{\circ} \mathrm{C} / 240 \mathrm{MPa}$ based on the prospective service temperature of the alloy and the early studies of the alloy. These experimental conditions can control the stress rupture lives within $1000 \mathrm{~h}$. The fracture surfaces and the longitudinal sections along the diameter within $10 \mathrm{~mm}$ from the fracture surfaces were observed.

All these samples were ground by $\mathrm{SiC}$ abrasive papers and then fine polished with $2.5-\mu \mathrm{m}$ diamond suspensions. Finally, the samples were all etched by a solution of $3 \mathrm{~g} \mathrm{CuSO}_{4}+10 \mathrm{ml} \mathrm{H}_{2} \mathrm{SO}_{4}+40 \mathrm{ml} \mathrm{HCl}+50 \mathrm{ml} \mathrm{H}_{2} \mathrm{O}$. The grain size and volume fractions of the carbides in the samples before stress rupture tests are measured. Each measured value is the average of 50 readings obtained from 50 different fields per sample. OM and SEM (HITACHI S-3400 N) were employed for the microstructure observation.

EPMA and XRD were employed for composition determination and phase identification, respectively. Some samples were mechanically dimpled and then ion-milled for TEM observation. A Tecnai G2F20 TEM with combination of energy-dispersive spectrum (EDS) was used in the present experiment, and the accelerating voltage was $200 \mathrm{kV}$.

\section{Results and Discussion}

\subsection{Microstructure}

The microstructure of the as-forged samples is presented in Fig. 1. It can be seen that the grain size is small, and there are lots of the blocky carbides and twin boundaries in the microstructure (Fig. 1a). Most of the carbides were located along the grain boundaries. The average diameter of the blocky carbides is about $2-7 \mu \mathrm{m}$. These carbides were $\mathrm{M}_{6} \mathrm{C}$ carbides determined by TEM (Fig. $1 \mathrm{~b}$ ).

Microstructures of the samples after solution treatment at different temperatures are shown in Figs. 2 and 3. It was shown that the grain size increased gradually with the increase in solution temperature, but the aging heat treatment at $900{ }^{\circ} \mathrm{C}$ for $2 \mathrm{~h}$ has no noticeable influence on the grain size (Fig. 2).

The primary carbides mainly located along the grain boundaries for the as-forged samples, as shown in Fig. 3a. Some of the carbides were dissolved after solution heat treatment, and the distribution of the remained carbides mainly located in the grain interior. Because the carbide was difficult to migrate, the distribution change of the primary carbides can be attributed to the grain boundary migration and grain mutual annexation. After aged at $900{ }^{\circ} \mathrm{C}$, fine secondary carbides precipitated along the grain boundaries rather than twin boundaries or grain interior, as shown in the inserted picture in Fig. 3e. The statistical analysis showed that the carbide volume fraction decreased noticeably after solution heat treated at $1220{ }^{\circ} \mathrm{C}$ (Fig. 3f).

XRD patterns of the aged samples are shown in Fig. 4. Compared with those of the as-forged and solution heattreated specimens, a new diffraction peak appeared in the aged specimens except the diffraction peak of $\gamma$ matrix and initial $\mathrm{M}_{6} \mathrm{C}$ carbides, and it was identified as $\mathrm{M}_{12} \mathrm{C}$ carbide.

Fine secondary carbides distributed homogeneously along the grain boundaries in the aged samples (Fig. 5). The SAED pattern reveals that the secondary carbides are $\mathrm{M}_{12} \mathrm{C}$ carbides, and the lattice parameter is determined to be $10.86 \AA$. The $\mathrm{M}_{12} \mathrm{C}$ carbides exhibit a coherent orientation relationship with $\gamma$ matrix.

Element distribution of the aged samples shows that the fine phase precipitated at the grain boundaries is rich in $\mathrm{Mo}, \mathrm{C}, \mathrm{Si}$ and depleted of $\mathrm{Cr}$ and $\mathrm{Fe}$ compared with the matrix (Fig. 6b-f).The quantitative element analysis showed that the mole ratio of the metal atoms and carbon atoms is nearly 12:1 (Table 2), which is consistent with the
Table 1 Nominal chemical composition of the experimental alloy (wt\%)

\begin{tabular}{lllllllll}
\hline Element & $\mathrm{Mo}$ & $\mathrm{Cr}$ & $\mathrm{Fe}$ & $\mathrm{C}$ & $\mathrm{Si}$ & $\mathrm{Mn}$ & $\mathrm{Ti}+\mathrm{Al}+\mathrm{Ta}$ & $\mathrm{Ni}$ \\
\hline Content $(\mathrm{wt} \%)$ & 16 & 7 & 4 & 0.04 & 0.45 & 0.5 & $<2$ & Bal. \\
\hline
\end{tabular}



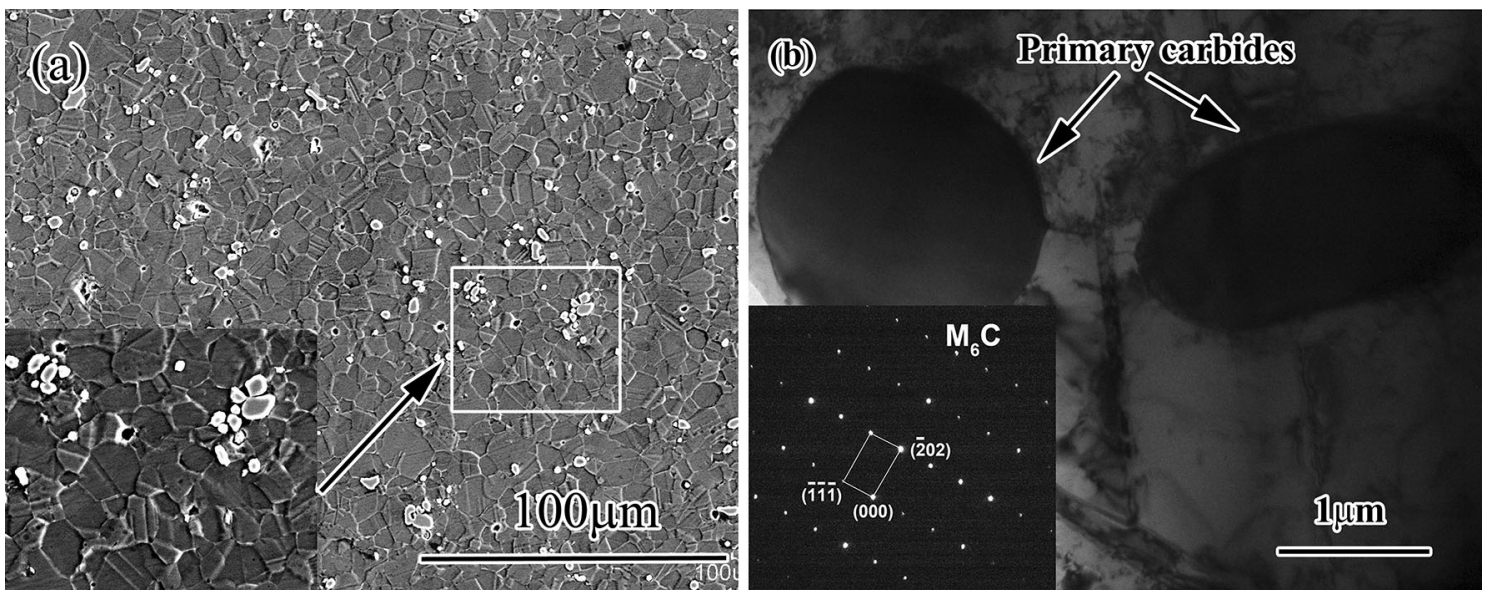

Fig. 1 Microstructure of the as-forged GH3535 alloy: a SEM image, b the TEM photographs with SAED pattern of the initial carbides inserted
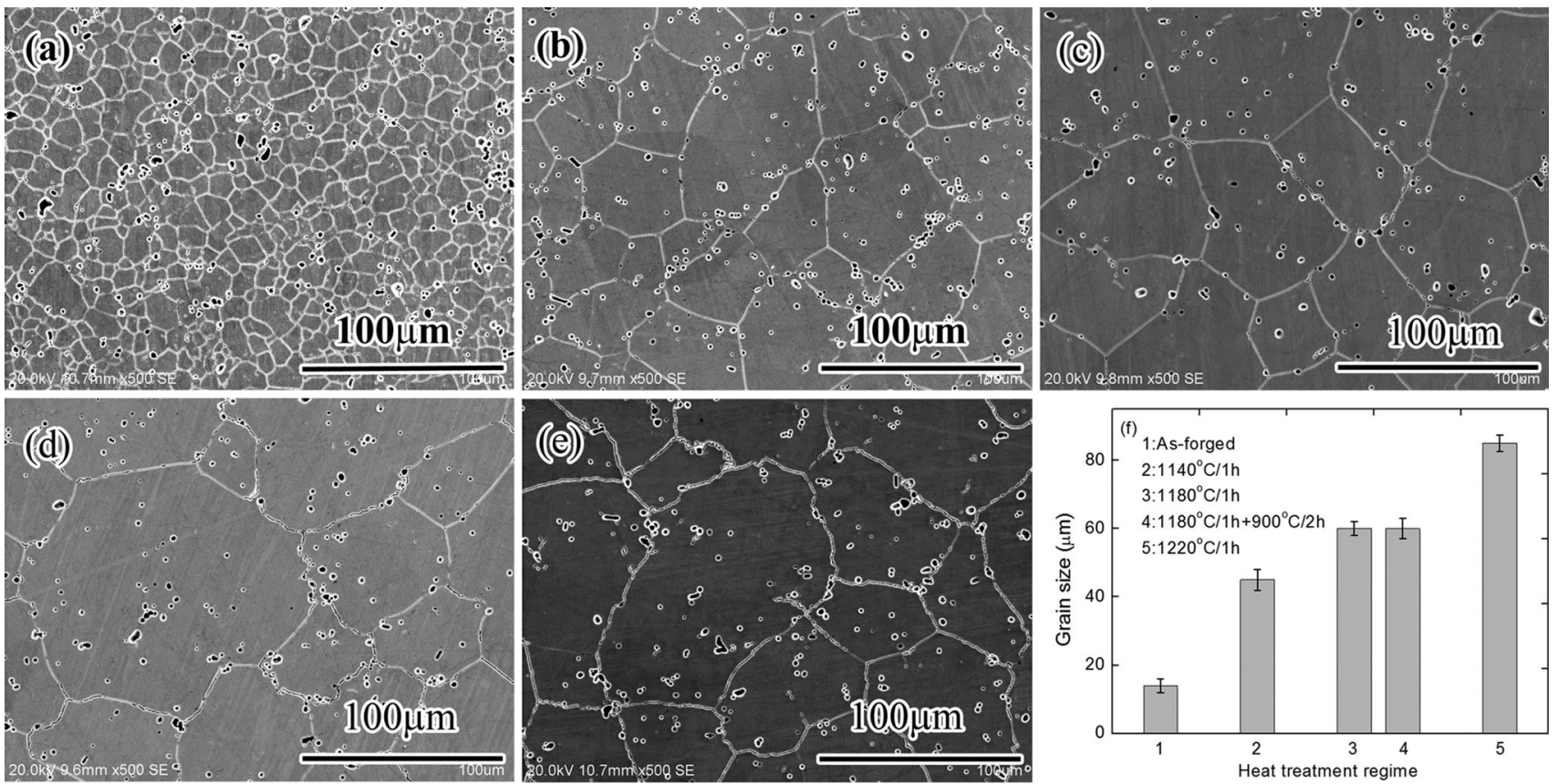

Fig. 2 Grains of the specimens after different heat treatments: a as-forged, b $1140{ }^{\circ} \mathrm{C} / 1 \mathrm{~h}$, c $1180{ }^{\circ} \mathrm{C} / 1 \mathrm{~h}, \mathbf{d ~} 1220{ }^{\circ} \mathrm{C} / 1 \mathrm{~h}$, e $1180{ }^{\circ} \mathrm{C} /$ $1 \mathrm{~h}+900{ }^{\circ} \mathrm{C} / 2 \mathrm{~h}, \mathbf{f}$ the grain size changes with heat treatment

$\mathrm{XRD}$ and TEM results that the secondary carbides precipitated along the grain boundaries were $\mathrm{M}_{12} \mathrm{C}$ carbides.

\subsection{Effect of Heat Treatment on Stress Ruptures Properties}

Stress rupture life and elongation of the samples with different heat treatment histories tested at $650{ }^{\circ} \mathrm{C} / 320 \mathrm{MPa}$ and $700{ }^{\circ} \mathrm{C} / 240 \mathrm{MPa}$ are shown in Fig. 7. It can be seen that the stress rupture life showed different trends with the increase in solution temperature under different test conditions (Fig. 7a). At $650{ }^{\circ} \mathrm{C} / 320 \mathrm{MPa}$, the stress rupture life of the solution treated samples showed a noticeable decrease compared with that of the as-forged samples, and decreased gradually along with the increase in solution temperature. However, the different trends were presented at $700{ }^{\circ} \mathrm{C} / 240 \mathrm{MPa}$. The stress rupture life increased from $140 \mathrm{~h}$ for the as-forged samples to $180 \mathrm{~h}$ for the $1140{ }^{\circ} \mathrm{C}$ solution treated samples, and then increased gradually with the increase in solution temperature to $1180{ }^{\circ} \mathrm{C}$, but a noticeable decrease appeared after solution treated at $1220{ }^{\circ} \mathrm{C}$. Under each test condition, the elongation decreased after solution heat treatment, and the elongation decreased gradually with the increase in solution temperature (Fig. 7b). After aging heat treatment, both the stress rupture life and elongation doubled compared with that of 

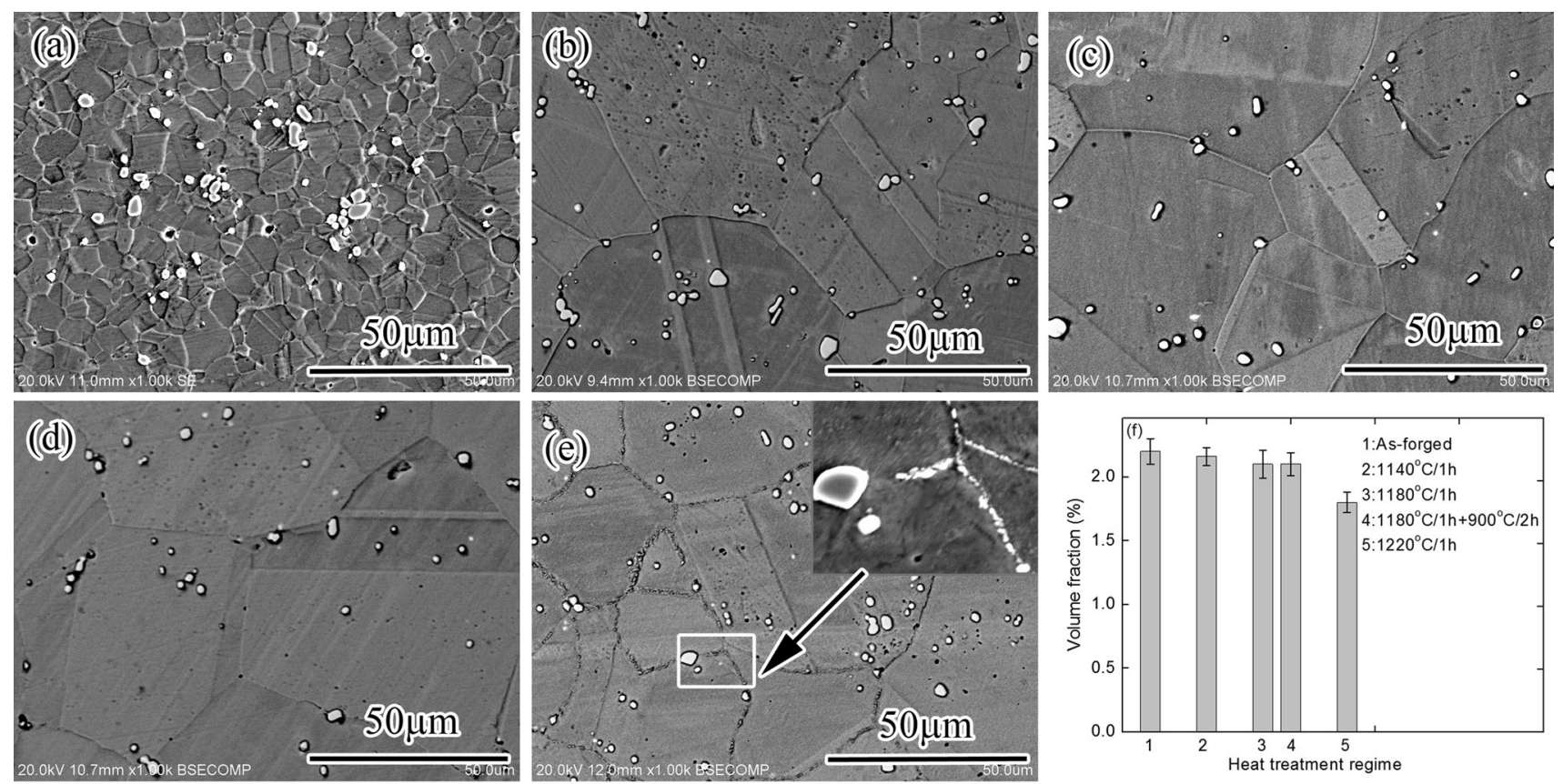

Fig. 3 Carbide morphology of the alloys under different heat treatment states: a as-forged, b $1140{ }^{\circ} \mathrm{C} / 1 \mathrm{~h}, \mathbf{c} 1180{ }^{\circ} \mathrm{C} / 1 \mathrm{~h}, \mathbf{d} 1220^{\circ} \mathrm{C} / 1 \mathrm{~h}$, e $1180^{\circ} \mathrm{C} / 1 \mathrm{~h}+900^{\circ} \mathrm{C} / 2 \mathrm{~h}, \mathbf{f}$ volume fractions of primary carbides in the alloys with different heat treatment histories

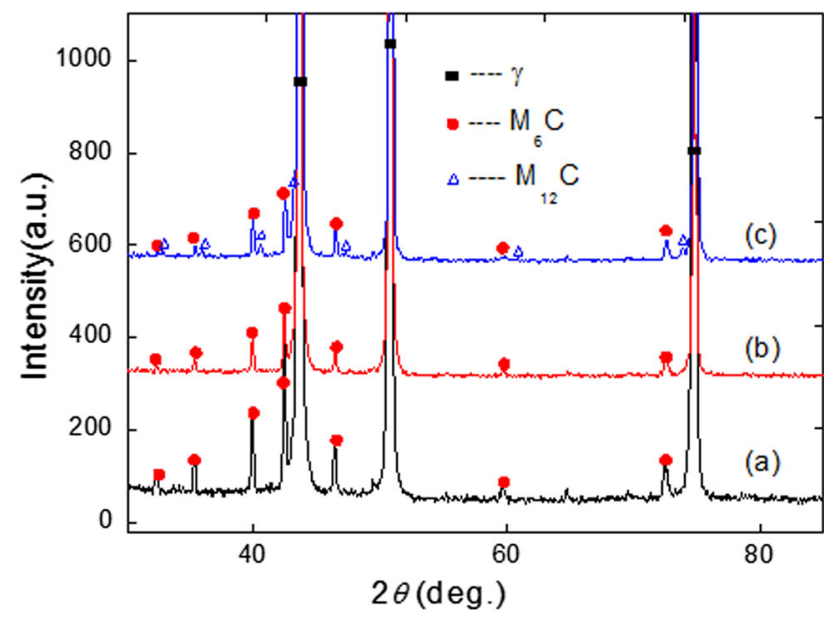

Fig. 4 X-ray diffraction patterns of a as-forged, b solution heattreated and $\mathbf{c}$ aged samples

the solution treated samples when tested at $650{ }^{\circ} \mathrm{C} /$ $320 \mathrm{MPa}$, but no noticeable improvement was detected when tested at $700{ }^{\circ} \mathrm{C} / 240 \mathrm{MPa}$ (Fig. 7a, b).

The fractographs of the samples tested at $650{ }^{\circ} \mathrm{C} /$ $320 \mathrm{MPa}$ are shown in Fig. 8. There were lots of the cavities in the as-forged sample, but the amount of the cavities decreased gradually with the increase in solution temperature (Fig. 8a-e). The $1180{ }^{\circ} \mathrm{C}$ solution treated sample exhibited intergranular fracture. However, the cavities appeared again after aged at $900{ }^{\circ} \mathrm{C}$. The morphologies of longitudinal sections are shown in Fig. 8f-o. Lots of secondary cracks appeared in the as-forged samples, and the

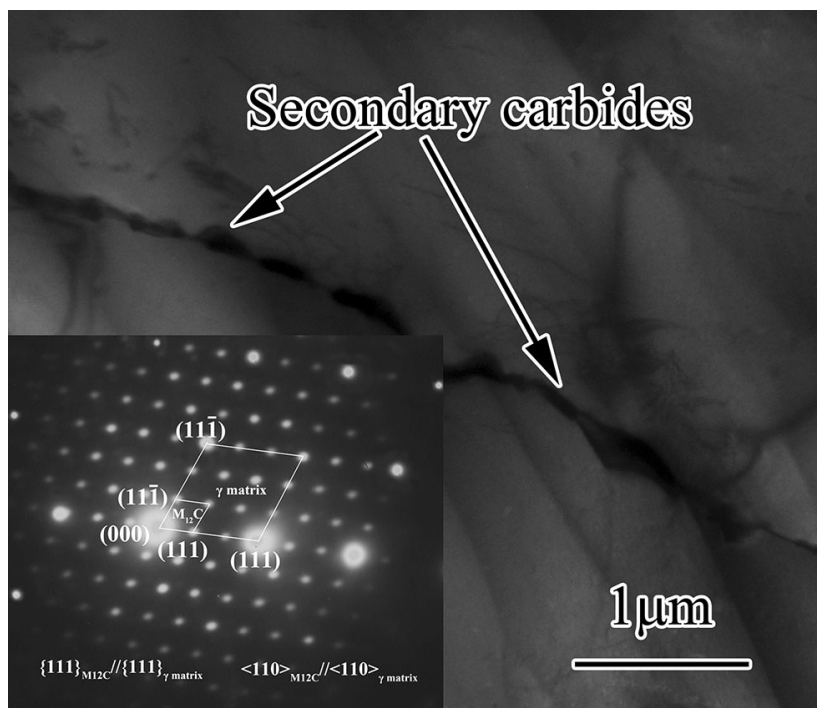

Fig. 5 Carbides precipitated along the grain boundaries in the $900{ }^{\circ} \mathrm{C}$ aged specimens: the morphology of the carbides and its SAED pattern

grains were noticeably elongated. Along with the increase in heat treatment temperature, the amount of secondary cracks decreased gradually and elongation of the grain also decreased. After aging treatment, the grains were greatly elongated and less secondary cracks were observed compared with the corresponding solution treated samples. Combining the morphology of the fracture surfaces and longitudinal sections, it can be concluded that the fracture mode of the samples is the mix of transgranular and 

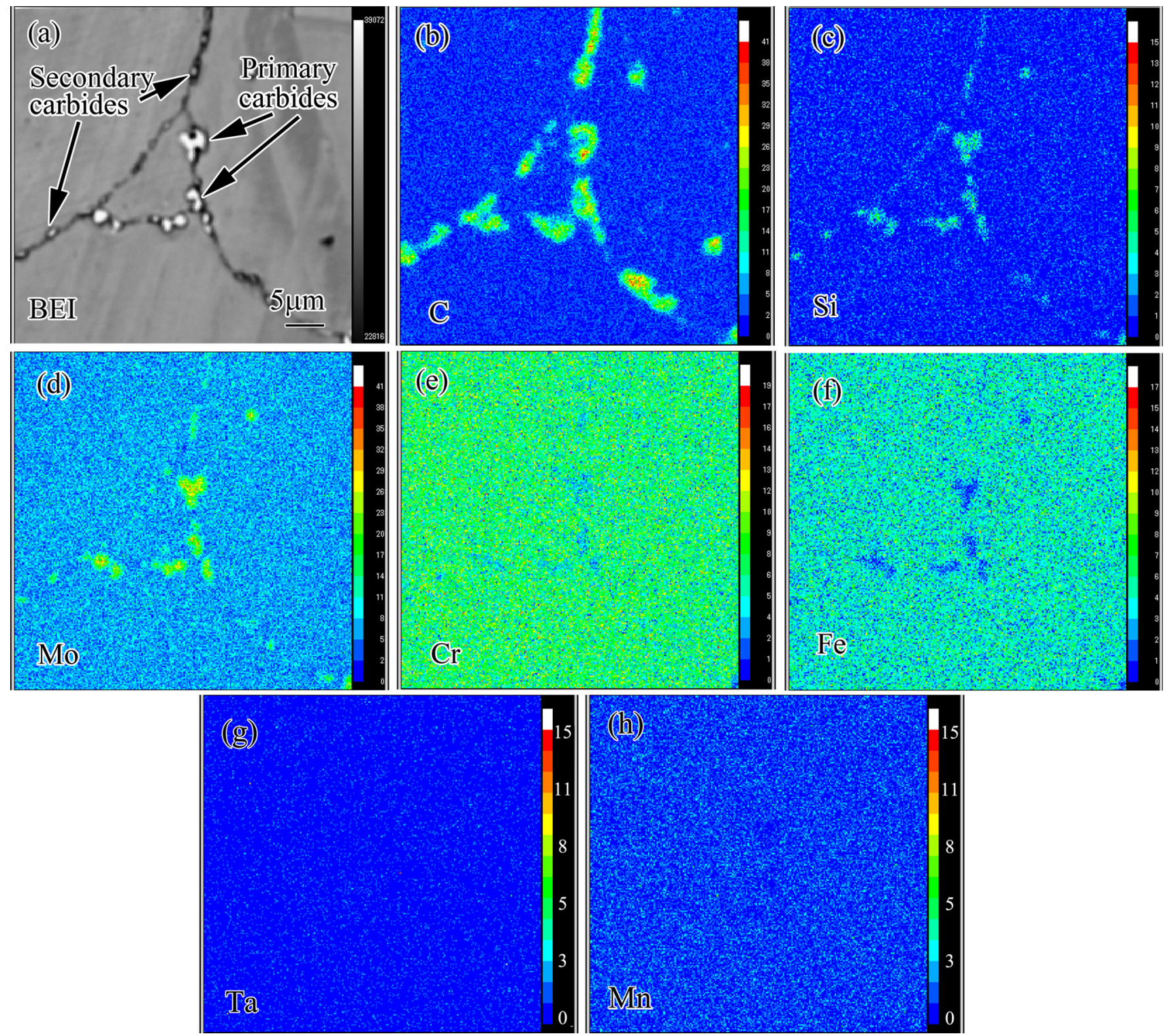

Fig. 6 EPMA results of the $900{ }^{\circ} \mathrm{C}$ aged specimen: a BEI image and the area distribution of $\mathbf{b ~ C}, \mathbf{c ~ S i}, \mathbf{d ~ M o , ~ e ~ C r , ~ f ~ F e , ~} \mathbf{g} \mathrm{Ta}, \mathbf{h} \mathrm{Mn}$

Table 2 Quantitative elemental analysis of primary and secondary carbides of aged alloy (at $\%)$

\begin{tabular}{lrrllll}
\hline Elements (at\%) & $\mathrm{C}$ & \multicolumn{1}{c}{$\mathrm{Si}$} & $\mathrm{Mo}$ & $\mathrm{Ni}$ & $\mathrm{Cr}$ & $\mathrm{Fe}$ \\
\hline Primary carbide & 13.05 & 9.01 & 36.98 & 31.04 & 5.79 & 2.15 \\
Secondary carbide & 7.52 & 11.73 & 39.02 & 37.94 & 1.75 & 1.28 \\
\hline
\end{tabular}

intergranular fracture except the samples after solution heat treatment at $1180{ }^{\circ} \mathrm{C}$ and $1220{ }^{\circ} \mathrm{C}$.

The fractographs of the samples tested at $700{ }^{\circ} \mathrm{C} /$ $240 \mathrm{MPa}$ are shown in Fig. 9. It can be seen that there were lots of cavities in all the samples except the $1220{ }^{\circ} \mathrm{C}$ solution treated sample. The morphology of the longitudinal sections of the samples is shown in Fig. 9. It can be seen that lots of secondary cracks in the as-forged samples and the grains were elongated noticeably (Fig. 9fo). Along with the increase in solution temperature, the amount of secondary cracks decreased gradually and the grain elongation decreased remarkably. After aging treatment, the grains were greatly elongated, and few secondary cracks could be observed. Combining the morphologies of the fracture surfaces and longitudinal sections of the samples, it can be concluded that the fracture mode is the mix of transgranular and intergranular fracture for all the samples except these samples solution treated at $1220{ }^{\circ} \mathrm{C}$, which only exhibited intergranular fracture character.

The details of the secondary carbides precipitated along the grain boundaries of the samples after creep tests are 

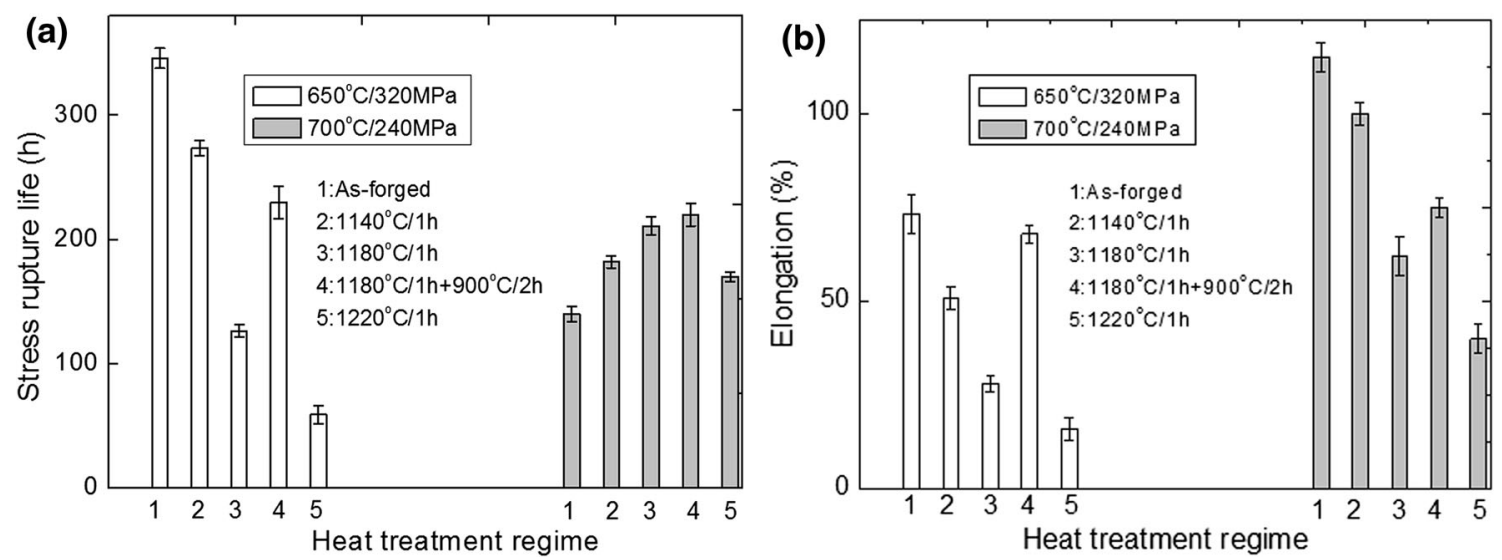

Fig. 7 Influence of heat treatment history on a stress rupture life, b elongation at $650{ }^{\circ} \mathrm{C} / 324 \mathrm{MPa}$ and $700{ }^{\circ} \mathrm{C} / 241 \mathrm{MPa}$

shown in Fig. 10. After creep test at $650{ }^{\circ} \mathrm{C} / 320 \mathrm{MPa}$, only a few fine carbides precipitated along the grain boundaries for the as-forged and solution heat-treated samples compared with those of the aged samples (Fig. 10a-d). However, large amount of secondary carbides were observed for all creep samples at $700{ }^{\circ} \mathrm{C} / 240 \mathrm{MPa}$ with different heat treatment regimes. This difference may be attributed to the formation of secondary carbide at high temperature during stress rupture test.

During $650{ }^{\circ} \mathrm{C} / 320 \mathrm{MPa}$ creep test, with the increase in solution temperature the grain size increased, while the creep rupture life decreased. The longer creep rupture life for the samples with smaller grains may be due to impediment effect of the grain boundaries on the dislocation movement [21-23]. When the samples were aged at $900{ }^{\circ} \mathrm{C}$ for $2 \mathrm{~h}$, the creep rupture lives almost doubled compared with those of the corresponding solution treated samples. This is probably due to the precipitation of fine $\mathrm{M}_{12} \mathrm{C}$ along the grain boundaries during aging. These carbides exhibited a coherent orientation relationship with the $\gamma$ matrix, which is beneficial for the stress rupture properties of the alloy [24-26]. It was reported that the fine carbides along the grain boundaries can prevent the dislocation movement and grain boundary sliding, and therefore, improve the stress rupture properties [11, 12, 27, 28]. Thus, the longer creep rupture life of the aged sample was mainly attributed to the reinforcement of the secondary carbides along the grain boundaries. However, the creep rupture life of the aged sample is shorter than that sample solution treated at $1140{ }^{\circ} \mathrm{C}$, from which it can be deduced that under this test conditions the grain size is much important than grain boundary reinforcement secondary particles.

When the test condition changed, the stress rupture life increased gradually with the increase in the solution temperature, but decreased for the samples solution treated at $1220^{\circ} \mathrm{C}$. On the one hand, creep temperature is an important factor. The equicohesive temperature (the temperature when the grain boundary strength be equal to grain interior strength) of the present alloy may be between $650{ }^{\circ} \mathrm{C}$ and $700{ }^{\circ} \mathrm{C}$, and when creep tested at $700{ }^{\circ} \mathrm{C}$, the grain boundaries were easy to become crack sources, which would lead to shorter stress rupture life [29, 30]. This is in agreement with the Shingledecker et al. and Yao et al. $[7,31]$. Thus, the stress rupture life of the samples may increase with the increase in the grain size when tested at $700{ }^{\circ} \mathrm{C} / 240 \mathrm{MPa}$. On the other hand, the grain size also has disadvantageous effect that should be considered. The better deformation coordination was resulted from the finer grains, the fine grains was easier to rotate, and the slip systems start in most grains which result in more grains can participate in deformation, the dislocations would not pile up seriously in finer grains, while coarse grains would generate stress concentration and initiate cracks more easily [32-34]. Another reason for this result can be attributed to the change in the grain boundary amount. The grain boundary amount decreased along with the increase in solid solution temperature, and the opportunity to form crack source in the alloy would decrease remarkably; therefore, the stress rupture properties increased along with the improvement in solid solution temperature. Therefore, the stress rupture life decreased with the increase in solution temperature. The stress rupture life decreased with the increase in solution temperature, and the decreased stress rupture life of the samples solution treated at $1220{ }^{\circ} \mathrm{C}$ can be attributed to the combined effect of the test temperature and grains size. Additionally, the amount of the carbides also has great influence on the stress rupture life [35-37]. The decrease in the initial carbide volume fraction of the samples solution treated at $1220{ }^{\circ} \mathrm{C}$ may be another reason for the decrease in stress rupture life. It may be probably due to the fast precipitation of the secondary carbides along the grain boundaries for other samples during $700{ }^{\circ} \mathrm{C} /$ $240 \mathrm{MPa}$ creep, and the stress rupture life of the sample 

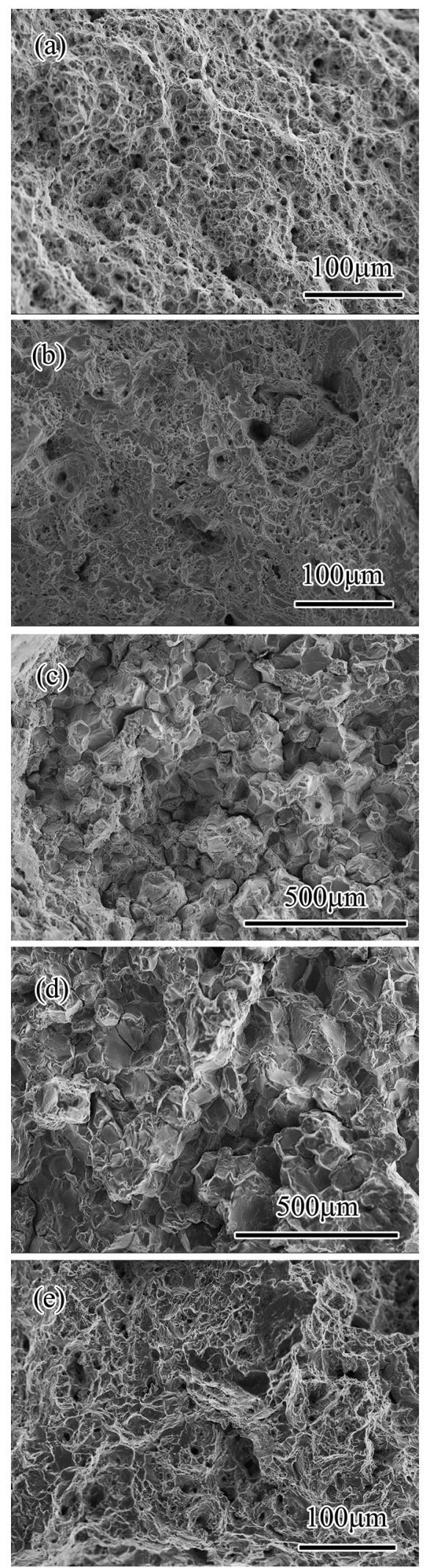
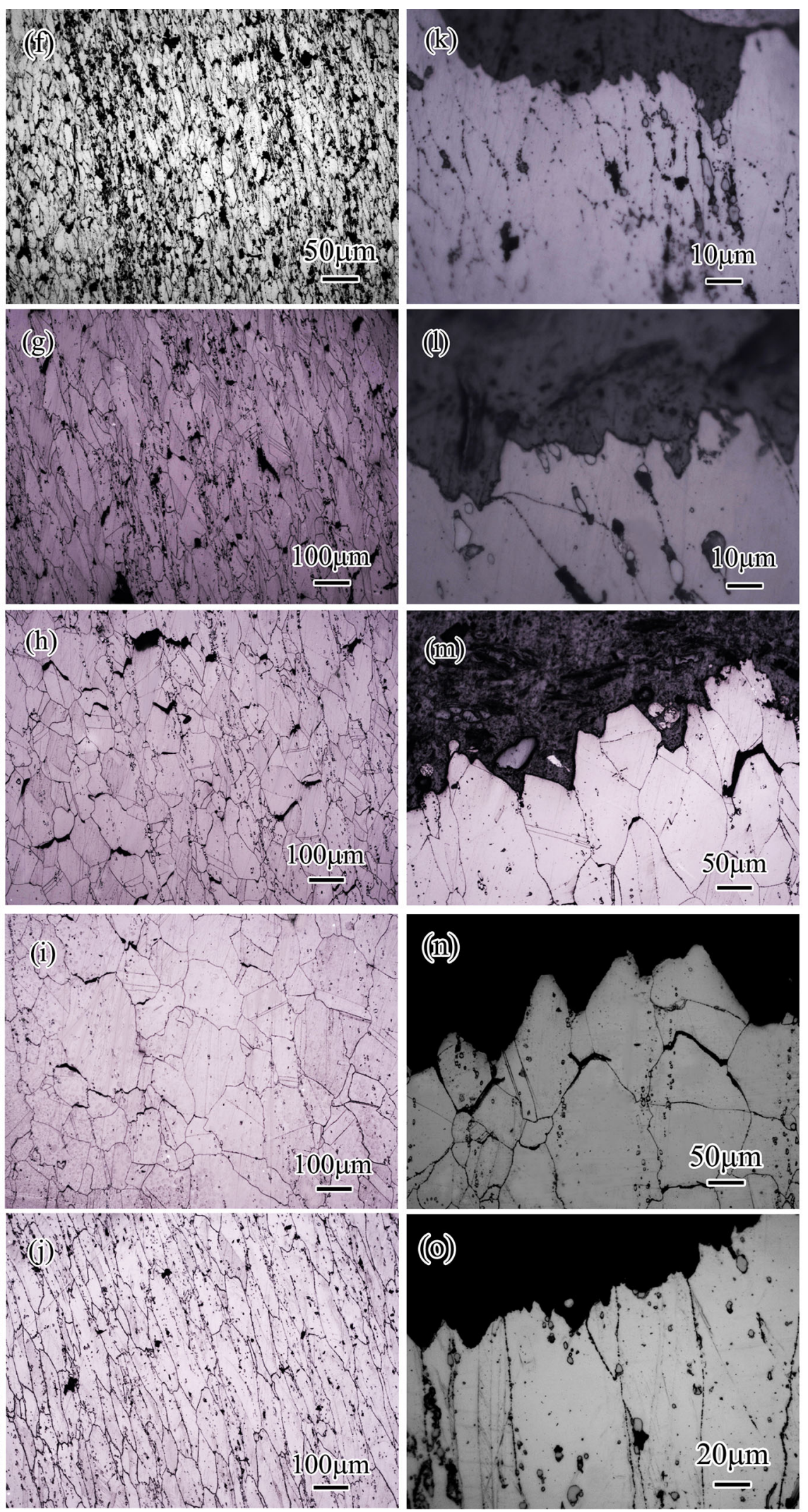

Fig. 8 Fracture morphologies of the samples tested at $650{ }^{\circ} \mathrm{C} / 324 \mathrm{MPa}$ : a, f, k as-forged, b, g, $\mathbf{l} 1140{ }^{\circ} \mathrm{C} / 1 \mathrm{~h}, \mathbf{c}, \mathbf{h}, \mathbf{m ~} 1180{ }^{\circ} \mathrm{C} / 1 \mathrm{~h}, \mathbf{d}, \mathbf{i}$, n $1220{ }^{\circ} \mathrm{C} / 1 \mathrm{~h}, \mathbf{e}, \mathbf{j}, \mathbf{o} 1180{ }^{\circ} \mathrm{C} / 1 \mathrm{~h}+900{ }^{\circ} \mathrm{C} / 2 \mathrm{~h}$. a-e Fracture surfaces, $\mathbf{f}-\mathbf{o}$ morphologies near the fracture surface on the transverse section 

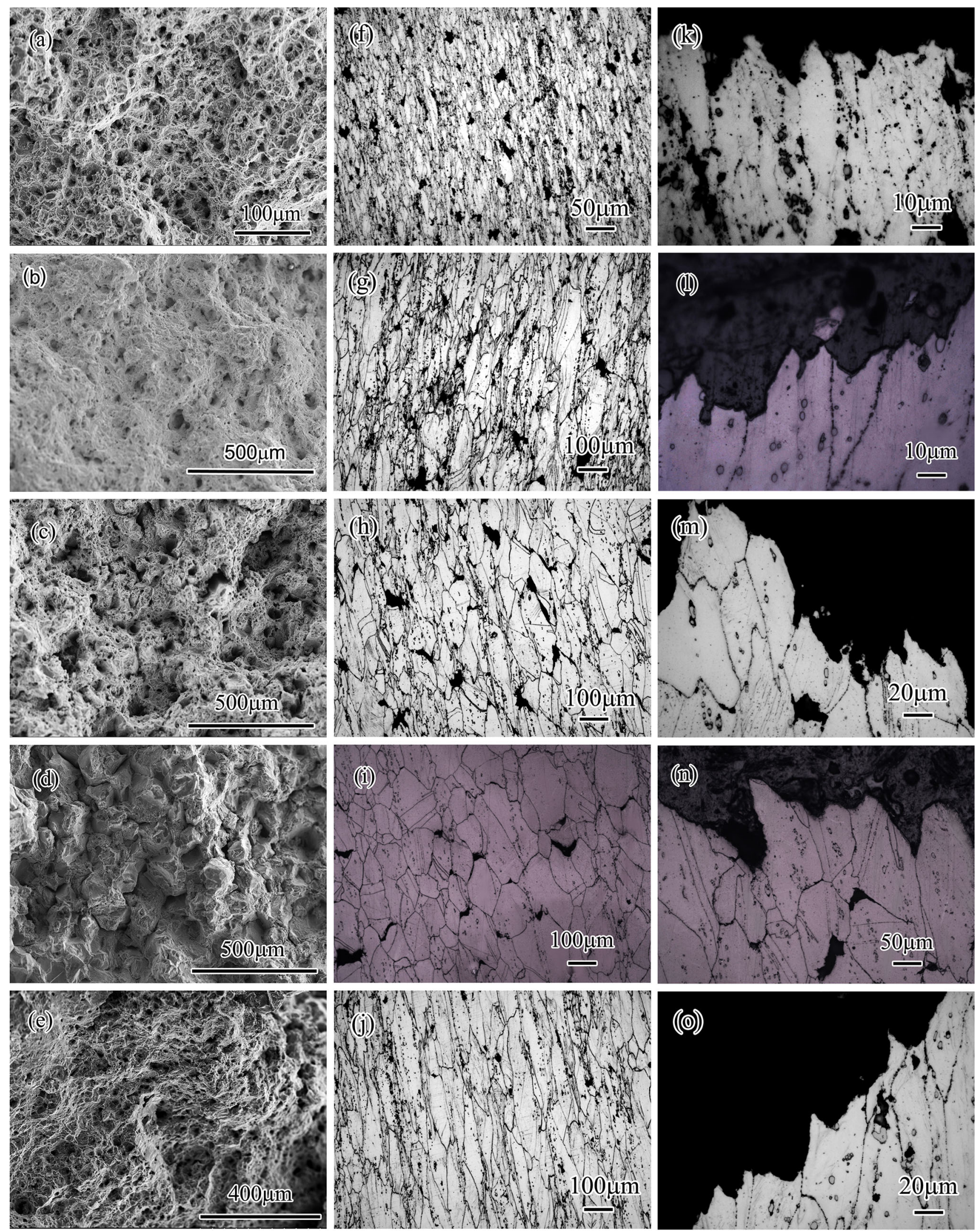

Fig. 9 Fracture morphologies of the samples tested at $700{ }^{\circ} \mathrm{C} / 240 \mathrm{MPa}$ : a, f, k As-forged, b, g, $\mathbf{l} 1140{ }^{\circ} \mathrm{C} / 1 \mathrm{~h}, \mathbf{c}, \mathbf{h}, \mathbf{m ~} 1180{ }^{\circ} \mathrm{C} / 1 \mathrm{~h}, \mathbf{d}, \mathbf{i}$, n $1220^{\circ} \mathrm{C} / 1 \mathrm{~h}, \mathbf{e}, \mathbf{j}, \mathbf{o} 1180{ }^{\circ} \mathrm{C} / 1 \mathrm{~h}+900{ }^{\circ} \mathrm{C} / 2 \mathrm{~h}$. a-e Fracture surface, $\mathbf{f}-\mathbf{o}$ morphology near the fracture surface on the transverse section 

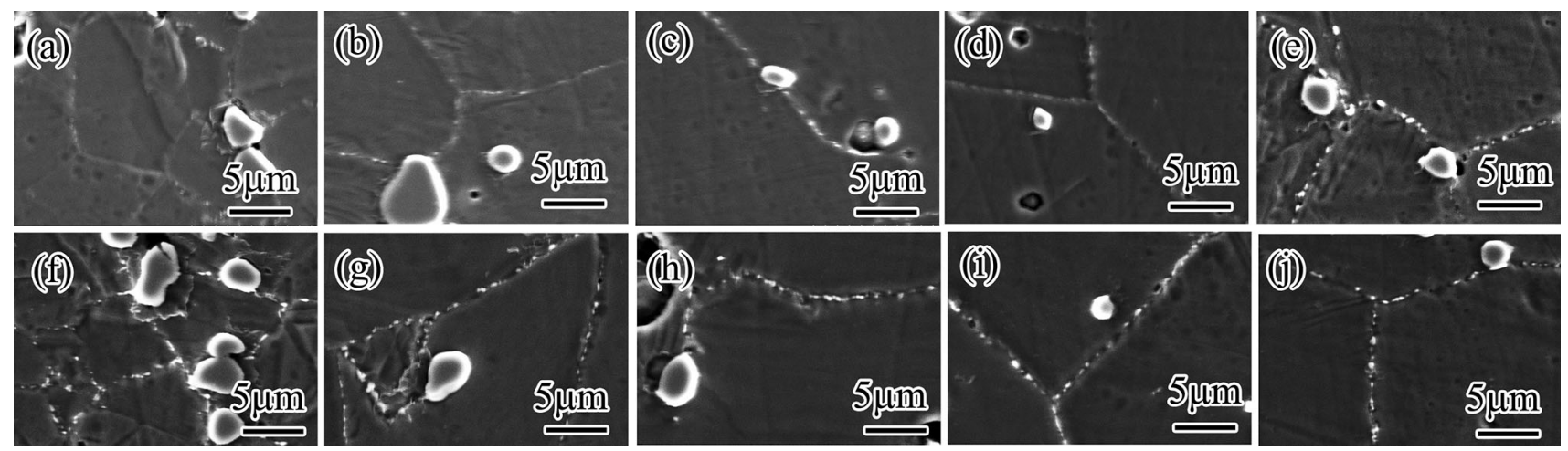

Fig. 10 Cross section images of the samples with different heat treatment histories after creep tests: a As-forged, b $1140{ }^{\circ} \mathrm{C} / 1 \mathrm{~h}, \mathbf{c} 1180{ }^{\circ} \mathrm{C} / 1 \mathrm{~h}$, d $1220{ }^{\circ} \mathrm{C} / 1 \mathrm{~h}$, e $1180{ }^{\circ} \mathrm{C} / 1 \mathrm{~h}+900{ }^{\circ} \mathrm{C} / 2 \mathrm{~h}$, tested at $650{ }^{\circ} \mathrm{C} / 320 \mathrm{MPa} ; \mathbf{f}$ As-forged, g $1140{ }^{\circ} \mathrm{C} / 1 \mathrm{~h}, \mathbf{h} 1180{ }^{\circ} \mathrm{C} / 1 \mathrm{~h}, \mathbf{i} 1220{ }^{\circ} \mathrm{C} / 1 \mathrm{~h}, \mathbf{j} 1180{ }^{\circ} \mathrm{C} /$ $1 \mathrm{~h}+900{ }^{\circ} \mathrm{C} / 2 \mathrm{~h}$, tested at $700{ }^{\circ} \mathrm{C} / 240 \mathrm{MPa}$

aged at $900{ }^{\circ} \mathrm{C}$ did not increase noticeably compared with that of the sample only solution treated at $1180^{\circ} \mathrm{C}$.

The elongation of solution heat-treated samples all decreased with the increase in heat treatment temperature under both test conditions which can be attributed to the better deformation coordination of the samples with the fine grains [38]. The grain size distributions of the alloy after different solid solution heat treatments are shown in Fig. 11. The grain size for the alloy after $1180^{\circ} \mathrm{C} / 1 \mathrm{~h}$ heat treatment has the smallest standard deviation (std) compared with the alloys after $1140{ }^{\circ} \mathrm{C} / 1 \mathrm{~h}$ and $1220^{\circ} \mathrm{C} / 1 \mathrm{~h}$.
The grain size for the alloy after $1180{ }^{\circ} \mathrm{C} / 1 \mathrm{~h}$ heat treatment also has the smallest coefficient of variation (CV) compared with other alloys (Fig. 11a-d). Additionally, large amount of fine $\mathrm{M}_{12} \mathrm{C}$ carbides precipitated along the grain boundaries during $700{ }^{\circ} \mathrm{C} / 240 \mathrm{MPa}$ creep. That may be the reason why the samples at $700{ }^{\circ} \mathrm{C} / 240 \mathrm{MPa}$ exhibit higher elongation compared with that of the samples tested at $650{ }^{\circ} \mathrm{C} / 320 \mathrm{MPa}$. The precipitation of secondary carbides along grain boundaries after aged at $900{ }^{\circ} \mathrm{C}$ should be responsible for the higher elongation of the aged samples compared with $1180{ }^{\circ} \mathrm{C}$ solution treated samples
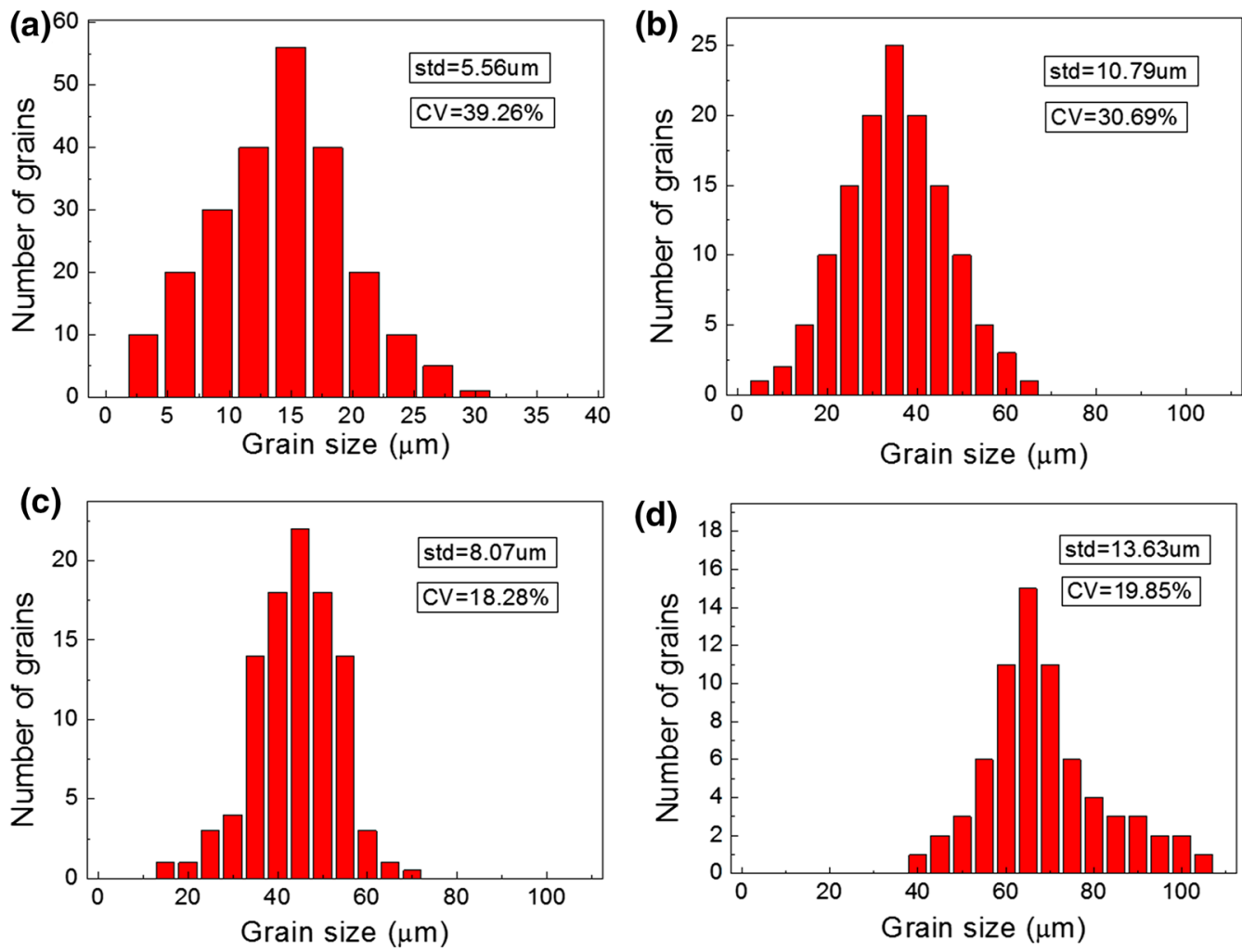

Fig. 11 Distribution of grain size: a As-forged, b $1140{ }^{\circ} \mathrm{C} / 1 \mathrm{~h}, \mathbf{c} 1180{ }^{\circ} \mathrm{C} / 1 \mathrm{~h}, \mathbf{d} 1220{ }^{\circ} \mathrm{C} / 1 \mathrm{~h}$ 
under test condition of $650{ }^{\circ} \mathrm{C} / 320 \mathrm{MPa}$. The influence mechanism of the secondary carbides on elongation can be explained that the grain boundaries were strengthened by the precipitation of secondary $\mathrm{M}_{12} \mathrm{C}$ carbides, that can cause the grain interior produce more deformation, and the higher elongation was obtained eventually.

From the above results, it can be concluded that different heat treatment histories will resulted in different microstructures, such as the grain size, carbides size, morphology, and distribution, which will lead to different stress rupture properties. At the same time, the test temperature (above or below equicohesive temperature) also has great influence on stress rupture properties.

\section{Conclusions}

1. The grain size of the Ni-Mo-Cr-Fe base corrosionresistant superalloy increased with the increase in solution temperature, the carbide's distribution changed from mainly along grain boundaries to mainly in grain interior, and its amount decreased noticeably after $1220{ }^{\circ} \mathrm{C}$ solution heat treatment. Fine $\mathrm{M}_{12} \mathrm{C}$ carbides precipitated along grain boundaries after $900{ }^{\circ} \mathrm{C}$ aging treatment.

2. The stress rupture life of the Ni-Mo-Cr-Fe base corrosion-resistant superalloy decreased with the increase in solution heat treatment temperature in $650{ }^{\circ} \mathrm{C} / 320 \mathrm{MPa}$ creep test, but the stress rupture life increased at first and then decrease for the samples solution treated at $1220{ }^{\circ} \mathrm{C}$ in $700{ }^{\circ} \mathrm{C} / 240 \mathrm{MPa}$ creep test. The elongation decreased with the increase in solution temperature for all samples under both test conditions. The stress rupture properties increased in both test conditions for all the samples after aged at $900{ }^{\circ} \mathrm{C}$ for $2 \mathrm{~h}$. These phenomena can be attributed to equicohesive temperature of the alloy (about between $650{ }^{\circ} \mathrm{C}$ and $700{ }^{\circ} \mathrm{C}$ ), grain size and the precipitation of secondary carbides.

Acknowledgements This work was supported by National Natural Science Foundation of China under Grant no. 51601078 and the "Strategic Priority Research Program" of the Chinese Academy of Sciences (Grant No. XDA020404040). The authors are grateful for these financial supports.

\section{References}

[1] M.W. Rosenthal, P.R. Kasten, R.B. Briggs, Molten salt reactors history, status, and potential. Nucl. Appl. Technol. 8, 107 (1970)

[2] U.S. DOE Nuclear Energy Research Advisory Committee, A technology roadmap for generation IV nuclear energy systems, DOE. GIF-002-00, 33 (2002)
[3] H. Inouye, W.D. Manly, T.K. Roche, Nickel base alloy, United States Patent, No. 2921850 (1960)

[4] H.E. McCoy Jr, Nickel base alloy, United States Patent, No. 3576622 (1971)

[5] M.W. Rosenthal, P.N. Haubenreich, R.B. Briggs, The development status of molten salt breeder reactors, ORNL-4812 (1972)

[6] T. Liu, J.S. Dong, L. Wang, Z.J. Li, X.T. Zhou, L.H. Lou, J. Zhang, Effect of long-term thermal exposure on microstructure and stress rupture properties of GH3535 superalloy. J. Mater. Sci. Technol. 31, 269 (2015)

[7] J.P. Shingledecker, N.D. Evans, G.M. Pharr, Influences of composition and grain size on creep-rupture behavior of Inconel alloy 740. Mater. Sci. Eng. A 578, 277 (2013)

[8] T. Jayakumar, M.D. Mathew, K. Laha, High temperature materials for nuclear fast fission and fusion reactors and advanced fossil power plants. Procedia Eng. 55, 259 (2013)

[9] Z.H. Yao, J.X. Dong, M.Y. Zhang, Q.Y. Yu, L. Zheng, Effect of solution temperature on microstructure and properties of GH864 alloy. Trans. Mater. Heat Treat. 32, 44 (2011). (in Chinese)

[10] C.X. Yang, Y.L. Xu, H. Nie, X.S. Xiao, G.Q. Jia, Z. Shen, Effects of heat treatments on the microstructure and mechanical properties of Rene 80. Mater. Des. 43, 66 (2013)

[11] L.R. Liu, T. Jin, N.R. Zhao, X.F. Sun, H.R. Guan, Z.Q. Hu, Formation of carbides and their effects on stress rupture of a Nibase single crystal superalloy. Mater. Sci. Eng. A 361, 191 (2003)

[12] Y.L. Xu, C.X. Yang, Q.X. Ran, P.F. Hu, X.S. Xiao, X.L. Cao, G.Q. Jia, Microstructure evolution and stress-rupture properties of Nimonic 80A after various heat treatments. Mater. Des. 47, 218 (2013)

[13] P.L. Mao, Y. Xin, K. Han, W.G. Jiang, Effects of heat treatment and re-content on the TCP-phase in two Ni-Mo-Cr-Re superalloys. Acta Metall. Sin. 22, 365 (2009)

[14] H. Tanaka, M. Murata, F. Abe, K. Yagi, The effect of carbide distributions on long-term creep rupture strength of SUS321H and SUS347H stainless steels. Mater. Sci. Eng. A 1049, 234-236 (1997)

[15] C.M. Kuo, Y.T. Yang, H.Y. Bor, C.N. Wei, C.C. Tai, Aging effects on the microstructure and creep behavior of Inconel 718 superalloy. Mater. Sci. Eng. A 289, 510-511 (2009)

[16] A. Chamanfar, L. Sarrat, M. Jahazi, M. Asadi, A. Weck, A.K. Koul, Microstructural characteristics of forged and heat treated Inconel-718 disks. Mater. Des. 52, 791 (2013)

[17] E. Gariboldi, M. Cabibbo, S. Spigarelli, D. Ripamonti, Investigation on precipitation phenomena of $\mathrm{Ni}-22 \mathrm{Cr}-12 \mathrm{Co}-9 \mathrm{Mo}$ alloy aged and crept at high temperature. Int. J. Pres. Ves. Pip. 85, 63 (2008)

[18] F. Torster, G. Baumeister, J. Albrecht, G. Liitjering, D. Helm, M.A. Daeubler, Influence of grain size and heat treatment on the microstructure and mechanical properties of the nickel base superalloy U 720 LI. Mater. Sci. Eng. A 189, 234-236 (1997)

[19] R.F. Zhou, The influence of forging parameters on structure and properties of superalloys. J. Mater. Eng. 1, 9 (1991). (in Chinese)

[20] R.C. Robertson, MSRE Design and Operations Report, Part I, Description of Reactor Design, ORNL-TM-0782, 1965

[21] J.C.M. Li, Y.T. Chou, The role of dislocations in the flow stress grain size relationships. Met. Trans. I, 1145 (1970)

[22] T.L. Johnston, C.E. Feltner, Grain size effects in the strain hardening of polycrystals. Met. Trans. I, 1161 (1970)

[23] L.X. Du, S.J. Yao, X.H. Liu, G.D. Wang, Growth behavior of ultrafine austenite grains in microalloyed steel. Acta Metall. Sin. 22, 7 (2009)

[24] C.Y. Chen, H.W. Yen, F.H. Kao, W.C. Li, C.Y. Huang, J.R. Yang, S.H. Wang, Precipitation hardening of high-strength low- 
alloy steels by nanometer-sized carbides. Mater. Sci. Eng. A 499, 162 (2009)

[25] Y.L. Xu, Q.M. Jin, X.S. Xiao, X.L. Cao, G.Q. Jia, Y.M. Zhu, H.J. Yin, Strengthening mechanisms of carbon in modified nickel-based superalloy Nimonic 80A. Mater. Sci. Eng. A 528, 460 (2011)

[26] X.J. Di, X.Q. Liu, C.X. Chen, B.S. Wang, X.J. Guo, Effect of post-weld heat treatment on the microstructure and corrosion resistance of deposited metal of a high-chromium nickel-based alloy. Acta Metall. Sin. 29, 1136 (2016)

[27] C.X. Yang, Y.L. Xu, Z.X. Zhang, H. Nie, X.S. Xiao, G.Q. Jia, Z. Shen, Improvement of stress-rupture life of GTD-111 by second solution heat treatment. Mater. Des. 45, 308 (2013)

[28] X.L. Pan, M. Umemoto, Precipitation characteristics and mechanism of vanadium carbides in a V-microalloyed mediumcarbon steel. Acta Metall. Sin. (2018). https://doi.org/10.1007/ s40195-018-0775-8

[29] K.Q. Ping, D. Yong, The role of grain boundaries in creep and creep rupture of metals. Mater. Sci. Prog. 2, 1 (1988). (in Chinese)

[30] W.D. Fei, H.Y. Yue, L.D. Wang, Equicohesive temperature of the interface and matrix and its effect on the tensile plasticity of $\mathrm{Al}_{18} \mathrm{~B}_{4} \mathrm{O}_{33}$ whiskers reinforced aluminum composite at elevated temperature. Mater. Chem. Phys. 119, 515 (2010)

[31] X.X. Yao, H. Kim, Development of high strength nickel base cast superalloy with superior creep rupture life. J. Choi Scr. Mater. 35, 953 (1996)
[32] B.N. Du, J.X. Yang, C.Y. Cui, X.F. Sun, Effects of grain size on the high-cycle fatigue behavior of IN792 superalloy. Mater. Des. 65, 57 (2015)

[33] S.L. Yang, W.R. Sun, J.X. Wang, Z.M. Ge, S.R. Guo, Z.Q. Hu, Effect of phosphorus on mechanical properties and thermal stability of fine-grained GH761 alloy. J. Mater. Sci. Technol. 27, 539 (2011)

[34] S.L. Mannan, P. Rodriguez, The influence of grain size on creep rupture properties of type 316 stainless steel, in Proceedings of the 6th International Conference on Fracture (ICF6), New Delhi, India (1984)

[35] J.X. Yang, Q. Zheng, M.Q. Ji, X.F. Sun, Z.Q. Hu, Effects of different $\mathrm{C}$ contents on the microstructure, tensile properties and stress rupture properties of IN792 alloy. Mater. Sci. Eng. A 528, 1534 (2011)

[36] C.N. Wei, H.Y. Borb, L. Chang, The influence of carbon addition on carbide characteristics and mechanical properties of CM681LC superalloy using fine grain process. J. Alloys Compd. 509, 5708 (2011)

[37] Z.F. Xu, J.S. Dong, L. Jiang, Z.J. Li, X.T. Zhou, Effects of Si addition and long-term thermal exposure on the tensile properties of a Ni-Mo-Cr superalloy. Acta Metall. Sin. 28, 951 (2015)

[38] C.J. Wang, C.J. Wang, J. Xu, P. Zhang, D.B. Shan, B. Guo, Plastic deformation size effects in micro-compression of pure nickel with a few grains across diameter. Mater. Sci. Eng. A 636, 352 (2015) 